\section{Effects of fluazuron on the biological parameters of engorged females of Rhipicephalus microplus}

\author{
Efeitos do fluazuron em parâmetros biológicos de fêmeas \\ ingurgitadas de Rhipicephalus microplus
}

\begin{abstract}
Fabrício Nascimento Gaudêncio"*, Matheus Dias Cordeiro², Jaqueline Rodrigues de Almeida Valim³, Bruna de Azevedo Baêta르. Vania Rita Elias Pinheiro Bittencourt ${ }^{4}$, Adivaldo Henrique da Fonseca ${ }^{5}$, Isabele da Costa Angelo ${ }^{6}$ \& Jairo Pinheiro
\end{abstract}

'Médico veterinário, MSc. Laboratório de Biofísica, Departamento de Ciências Fisiológicas, Instituto de Ciências Biológicas e da Saúde, CPGCV, Universidade Federal Rural do Rio de Janeiro - UFRRJ, Seropédica, RJ, Brasil

2Médicos veterinários, DSc. Laboratório de Doenças Parasitárias, Departamento de Epidemiologia e Saúde Pública, Instituto de Veterinária, Universidade Federal Rural do Rio de Janeiro - UFRRJ, Seropédica, RJ, Brasil

3Médica veterinária, MSc. Laboratório de Doenças Parasitárias, Departamento de Epidemiologia e Saúde Pública, Instituto de Veterinária, Universidade Federal Rural do Rio de Janeiro - UFRRJ, Seropédica, RJ, Brasil

${ }^{4}$ Médica veterinária, DSc. Laboratório de Controle Microbiano, Departamento de Parasitologia Animal, Instituto de Veterinária, CPGCV, Universidade Federal Rural do Rio de Janeiro - UFRRJ, Seropédica, RJ, Brasil

${ }^{5}$ Médico veterinário, PhD. Laboratório de Doenças Parasitárias, Departamento de Epidemiologia e Saúde Pública, Instituto de Veterinária, CPGCV, Universidade Federal Rural do Rio de Janeiro - UFRRJ, Seropédica, RJ, Brasil

${ }^{6}$ Médica veterinária, DSc. Departamento de Epidemiologia e Saúde Pública, Instituto de Veterinária, Universidade Federal Rural do Rio de Janeiro, UFRRJ, Seropédica, RJ, Brasil

${ }^{7}$ Biólogo, DSc. Laboratório de Biofísica, Departamento de Ciências Fisiológicas, Instituto de Ciências Biológicas e da Saúde, CPGCV, Universidade Federal Rural do Rio de Janeiro - UFRRJ, Seropédica, RJ, Brasil

\begin{abstract}
The objective of this study was to evaluate the biological parameters of Rhipicephalus microplus engorged females exposed to the arthropod growth regulator fluazuron. A commercial formulation based on fluazuron (Acatak ${ }^{\otimes}$, Novartis) was administered topically to stabled cattle artificially infested with $R$. microplus larvae. The infestations occurred on four alternate days (days $-21,-17,-13$ and -6) taking as day 0 (zero) the day of treatment with a single dose of fluazuron for the treated group. Fifteen engorged females from each group were collected from the floor of the stalls at the end of the engorgement period (21 days) on pre-established days: before (day 0) and after treatment (days 4, 8 and 15), respectively. After cleaning and preparation of the engorged females in the laboratory, the following biological parameters were analyzed: weight of the engorged female, the weight of the female after laying (spent female), laying period, the weight of the posture, egg production index, reproductive efficiency index, hatching percentage, and nutritional index. The average weight of engorged females showed a significant reduction on all days after treatment in the exposed group. Aside from the weight after laying, all other biological parameters showed a significant reduction on the eighth post-treatment day due to exposure to fluazuron. Knowledge of the effects of an active principle on biological parameters in a population of ticks is essential for the appropriate implementation of integrated management practices for parasite control.
\end{abstract}

Keywords: benzoylphenylureas, growth regulator, hatching, posture.

\section{Resumo}

O objetivo deste estudo foi avaliar os parâmetros biológicos de fêmeas ingurgitadas de Rhipicephalus microplus expostas ao regulador de crescimento de artrópodes, fluazuron. Uma formulação comercial baseada em fluazuron (Acatak ${ }^{\circledR}$, Novartis) foi administrada topicamente a bovinos estabulados artificialmente infestados com larvas de R. microplus. As infestações ocorreram em quatro dias alternados (dias -21, -17,-13 e -6) tomando como dia 0 (zero) o dia do tratamento com uma dose única de fluazuron para o grupo tratado. Quinze fêmeas ingurgitadas de cada grupo foram coletadas do assoalho das baias ao final do período de ingurgitamento (21 dias) em dias pré-estabelecidos: antes (dia 0) e após o tratamento (dias 4, 8 e 15), respectivamente. Após limpeza e preparo das fêmeas ingurgitadas no laboratório, foram analisados os seguintes parâmetros biológicos: peso da fêmea ingurgitada, peso da fêmea após postura (fêmea gasta), período de postura, peso da postura, índice de produção de ovos, índice de eficiência reprodutiva, porcentagem de eclosão e índice nutricional. O peso médio das fêmeas ingurgitadas mostrou \section{B] M \\ Brazilian Journal of Veterinary Medicine \\ p-ISSN 0100-2430 \\ e-ISSN 2527-2179 \\ ○}

How to cite: Gaudêncio, F. N., Cordeiro, M. D., Valim, J. R. A., Baêta, B. A., Bittencourt, V. R. E. P. Fonseca, A. H., Angelo, I. C., \& Pinheiro, J. (2017). Effects of fluazuron on the biological parameters of engorged females of Rhipicephalus microplus. Brazilian Journal of Veterinary Medicine, 39(4) 231-238. doi: 10.29374/2527-2179.bjvm023017

Financial support: FNG and JRAV have a CAPES scholarship.

Conflict of interests: No conflict of interests declared concerning the publication of this article.

Received: July 23, 2016.

Accepted: March 02, 2017.

The study was carried out at Universidade Federal Rural do Rio de Janeiro - UFRRJ, RJ, Brasil.

\section{*Correspondence}

Fabrício Nascimento Gaudêncio

Departamento de Ciências Fisiológicas, Instituto de Ciências Biológicas e da Saúde, Universidade Federal Rural do Rio de Janeiro - UFRRJ

Rodovia BR 465, Km 7, Antiga estrada Rio-São

Paulo CEP 23890-000 - Seropédica (RJ), Brasil

E-mail: fabriciogaudencio@hotmail.com the terms of the Creative Commons Attribution Non-Commercial License which permits unrestricted non-commercial use, distribution, and reproduction in any medium provided the original work is properly cited. 
uma redução significativa em todos os dias após o tratamento no grupo exposto. Além do peso após a postura, todos os outros parâmetros biológicos mostraram uma redução significativa no oitavo dia pós-tratamento devido à exposição ao fluazuron. O conhecimento dos efeitos de um princípio ativo sobre parâmetros biológicos em uma população de carrapatos é essencial para a implementação adequada de práticas de manejo integrado para controle de parasitas.

Palavras-chave: benzoilfeniluréias, regulador de crescimento, eclosão, postura.

\section{Introduction}

The tick Rhipicephalus microplus (Canestrini, 1887), known as the cattle tick, is native to Asia but has been introduced in most tropical and subtropical countries by the importation of cattle (Pereira et al., 2008). This tick thus has global economic importance, since more than $75 \%$ of the bovine population is afflicted by the parasite, making it "enemy number one" of cattle breeders (Cordovés, 1997). In Brazil, the annual losses caused by this tick are estimated to be over US\$ 3 billion in lost production and costs for treatment (Grisi et al., 2014).

The exoskeleton of ticks is similar to that of other arthropods, serving as primary protection against water loss along with mechanical protection against other sources of damage (Sonenshine, 1991). The nature of the exoskeleton is closely associated with the ticks' growth, respiration, and locomotion. Knowledge of these aspects is necessary to develop chemical products able to penetrate the tegument and kill the ticks (Klowden, 2007). The main components of the cuticle of all arthropods are proteins and chitin (Sonenshine, 1991). Chitin is an amino polysaccharide homopolymer composed of N-acetyl-D-glucosamine units (GlcNAc) (Cohen, 1987; Palli \& Retnakaran, 1999). Its synthesis involves multiple cell activities, starting with biotransformation of simple metabolites and culminating with a polymer released by the cell membrane (Cohen,1987).

The benzoylphenyl ureas are molecules that inhibit the synthesis of chitin in arthropods, acting mainly on larvae during the molting process (Vasuki \& Rajavel, 1992). Fluazuron is a substance belonging to the benzoylphenyl urea class used as an ectoparasiticide in the veterinary market. It inhibits the growth and development of arthropods by inhibiting the formation and deposition of chitin, a process that occurs starting with embryogenesis, passing though all instars until the blood-feeding adult stage. Therefore, fluazuron interrupts the life cycle of ticks by interfering with the formation of chitin (World Health Organization, 1998).

Because of the importance of chitin synthesis for adequate development of ticks during their life cycle, especially for larval hatching, the objective of this study was to assess possible changes in the biological parameters of $R$. microplus females fed on calves exposed to the arthropod growth regulator fluazuron.

\section{Materials and methods}

\section{Ethical considerations}

This study was approved by the committee on ethical experimentation with animals of Rio de Janeiro Federal Rural University (CEUA-UFRRJ) under protocol number 023/2015.

\section{Experimental procedure}

Mestizo's calves were used (Dutch-Gyr cross), with ages from six months to one year, kept in individual stalls on the campus of UFRRJ.

Three animals were allocated to the control group and three were treated with the commercial product Acatak ${ }^{\circledast}$ (active ingredient fluazuron) at the dose recommended by the manufacturer (2.5mg/kg; $10 \mathrm{ml}$ of Acatak for each $100 \mathrm{~kg}$ of live weight), administered topically (poured on).

All the animals were infested with $R$. microplus larvae (each animal received larvae from $1 \mathrm{~g}$ of eggs, with age of 15 days after hatching). The infestations occurred on four alternate days before treatment (days $-21,-17,-13$ and -6), with day 0 (zero) being the day of treatment with fluazuron. Twenty-one days after each treatment day, the females that had naturally dropped off the host were collected from the floor of the stalls. In other words, the ticks from the infestation of day -21 were collected on day zero (before treatment), while those from day -17 were collected on day 


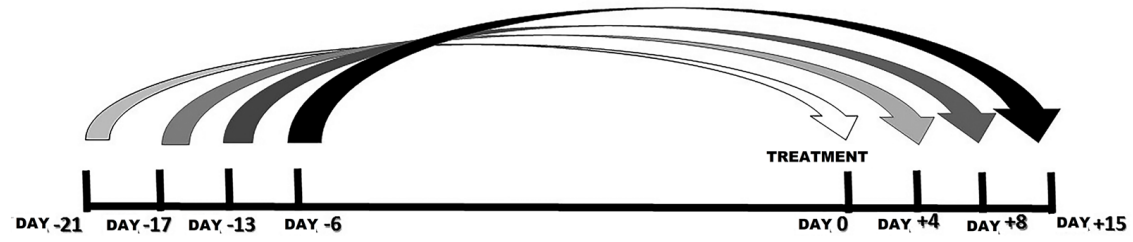

Figure 1. Organogram showing the infestation days (Day-21,-17,-13 and -6) of the cattle with Rhipicephalus microplus larvae and the respective days of collecting engorged females (Day $0,+4,+8$ and +15 ) as of the treatment with fluazuron.

+4 , those from day -13 on day +8 , and those from -6 on day +15 . Figure 1 depicts the procedure for infestation with the respective dates of collecting the engorged females.

\section{Evaluation of the biological parameters}

For assessment of the biological parameters, 15 engorged females of each group collected on each recovery day were weighed individually and placed in Petri dishes, fixed in the dorsal position with two-sided sticky tape and kept in a controlled climate chamber at temperature of $27 \pm 1^{\circ} \mathrm{C}$ and relative air humidity of $80 \pm 5 \%$, where they were monitored daily for oviposition. The biological parameters evaluated were: engorged female weight, total posture weight, posture period (days in the interval between first and last day of laying), egg production index (Bennett, 1974), reproduction efficiency index (Meléndez et al., 1998), nutritional index (Bennett 1974), and hatching percentage (visual estimation of number of hatched larvae in relation to total number of eggs laid by each female). At the end of the posture period, defined as after three consecutive days without laying, the spent females were weighed again.

\section{Statistical analysis}

The means of the results of the biological parameters engorged female weight spent female weight and posture period was submitted to analysis of variance (ANOVA), followed by the Tukey test, at $5 \%$ significance. The results are expressed as a mean \pm standard deviation.

All the other parameters were submitted to the Kruskal-Wallis test followed by the Dunn test for comparison of the means, at the significance of $5 \%$. These results are expressed as a mean \pm standard error. The statistical calculations were performed using InStat, GraphPad v.4.00 and v.3.02, Prism, Inc.).

\section{Results}

Differences were noted between the control and exposed groups regarding the morphology of the engorged females, mainly on the 8th and 15th days after treatment (DAT) (Figure 2). The engorged females of the exposed group were smaller, with loss of characteristic longitudinal grooves and body conformation, along with greater opacity of the dorsal surface (loss of characteristic shine).

There was no statistical differenced $(p>0.05)$ for the mean initial weight of the engorged females at time 0 (control - 286.08 \pm 47.77 mg; exposed - 261.21 $\pm 39.23 \mathrm{mg}$ ). However, fluazuron caused a significant reduction $(p<0.05)$ in the weight of the engorged females on all the other observation days after treatment, with a significantly decreasing trend in the average weight of the females as time progressed (Figure 3 ) between the $4^{\text {th }}$ and $15^{\text {th }}$ days.

With respect to laying period, there was a significant difference between the control group on day 0 (16.4 \pm 4.45 days) and the exposed group on day 8 ( $9.55 \pm 3.39$ days) and between the control group on day 8 (15.61 \pm 3.90 days) and exposed group on day $8(p<0.05)$. There also were significant differences in the comparison of the exposed group on some days (Table 1). On day 0 there was no significant statistical difference $(p>0.05)$ between the control $(161.35 \pm 8.25 \mathrm{mg})$ and exposed groups (139.91 $\pm 10.01 \mathrm{mg})$.

In the comparison between the groups regarding the egg production index (EPI) on the same evaluation day, a significant difference ( $p<0.05)$ only occurred between the control and exposed groups on the $8^{\text {th }}$ day $(49.83 \pm 3.68 \%$ and $12.63 \pm 3.9 \%$, respectively). 


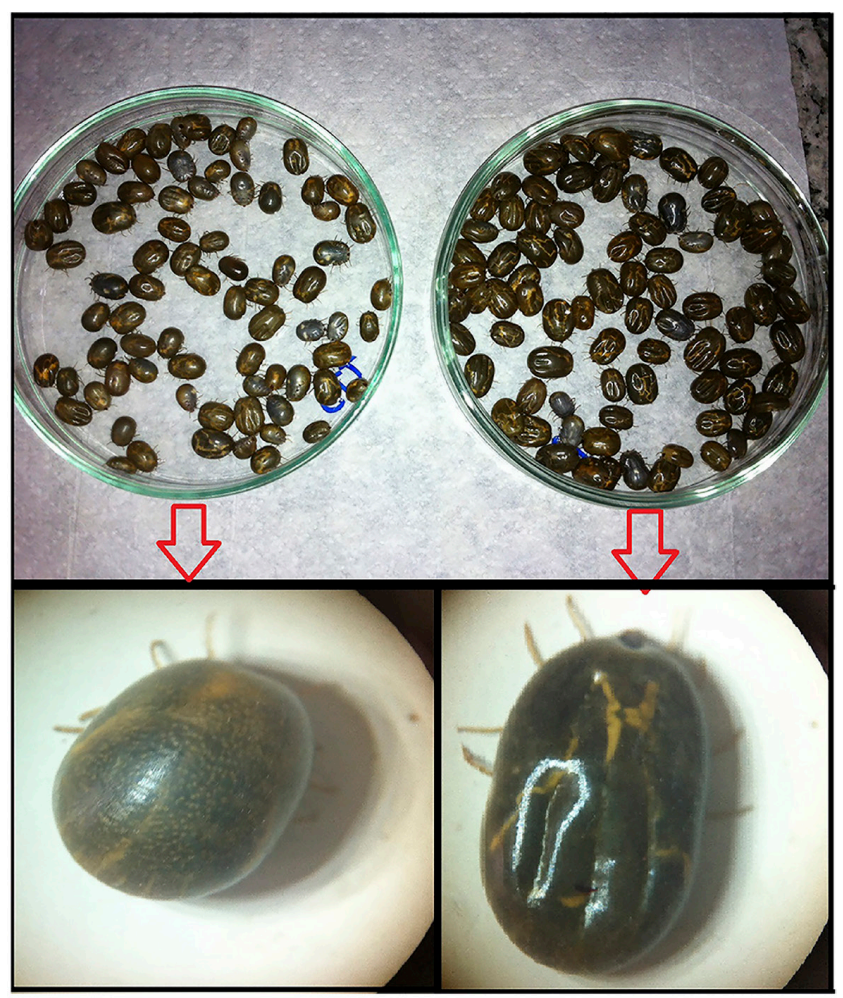

Figure 2. Comparison of the Rhipicephalus microplus females of the group exposed to fluazuron (left) and control (right) observed under a stereoscopic microscope, collected from the ground of stalls on the eighth day after treatment of the calves. Note the differences in shape, size and dorsal surface aspect of the females.

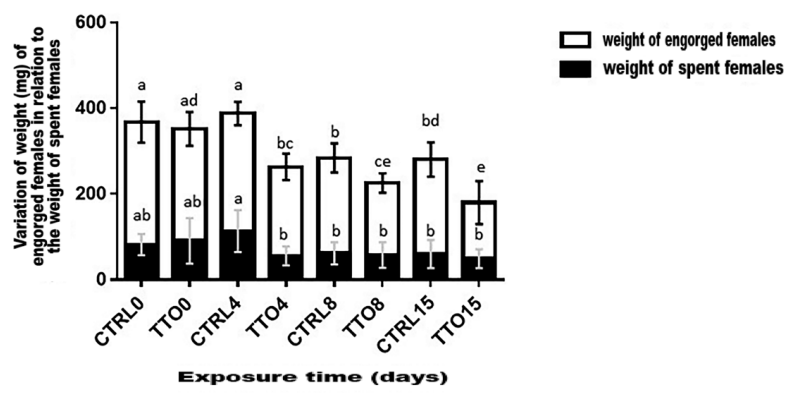

Figure 3. Variation of weight (mg) of engorged females (white bars) in relation to the weight of spent females (black bars) in function of exposure time to the product: CTRL (control); TTO (exposed to fluazuron). Mean \pm standard deviation. Equal letters do not differ significantly between each other $(p>0.05)$ by the Tukey test.

With respect to the reproduction efficiency index (REI), there was a significant difference $(p<0.05)$ between the control $(42.12 \pm 5.63 \%)$ and exposed groups on the $8^{\text {th }}$ day after treatment $(0.056 \pm 0.056 \%)$. There also was a significant difference $(p<0.05)$ between the exposed group on day 8 and the other groups on different days after exposure: control day O (42.96 $\pm 5.37 \%)$, control day $15(43.55 \pm 4.55 \%)$, exposed day $0(43.36 \pm 4.49 \%)$ and exposed day $4(30.13 \pm 3.49 \%)$, the last one the smallest average for this parameter.

The lowest egg hatching rate in the exposed group occurred on the 8th DAT (0.33 $\pm 0.33 \%)$. There was a significant difference $(p<0.05)$ between this group and the control on all the observation days, including the exposed group on day 0 (80.2 $\pm 6.63 \%$ ). Therefore, the strongest effect of the treatment on this parameter happened on the 8th DAT. 


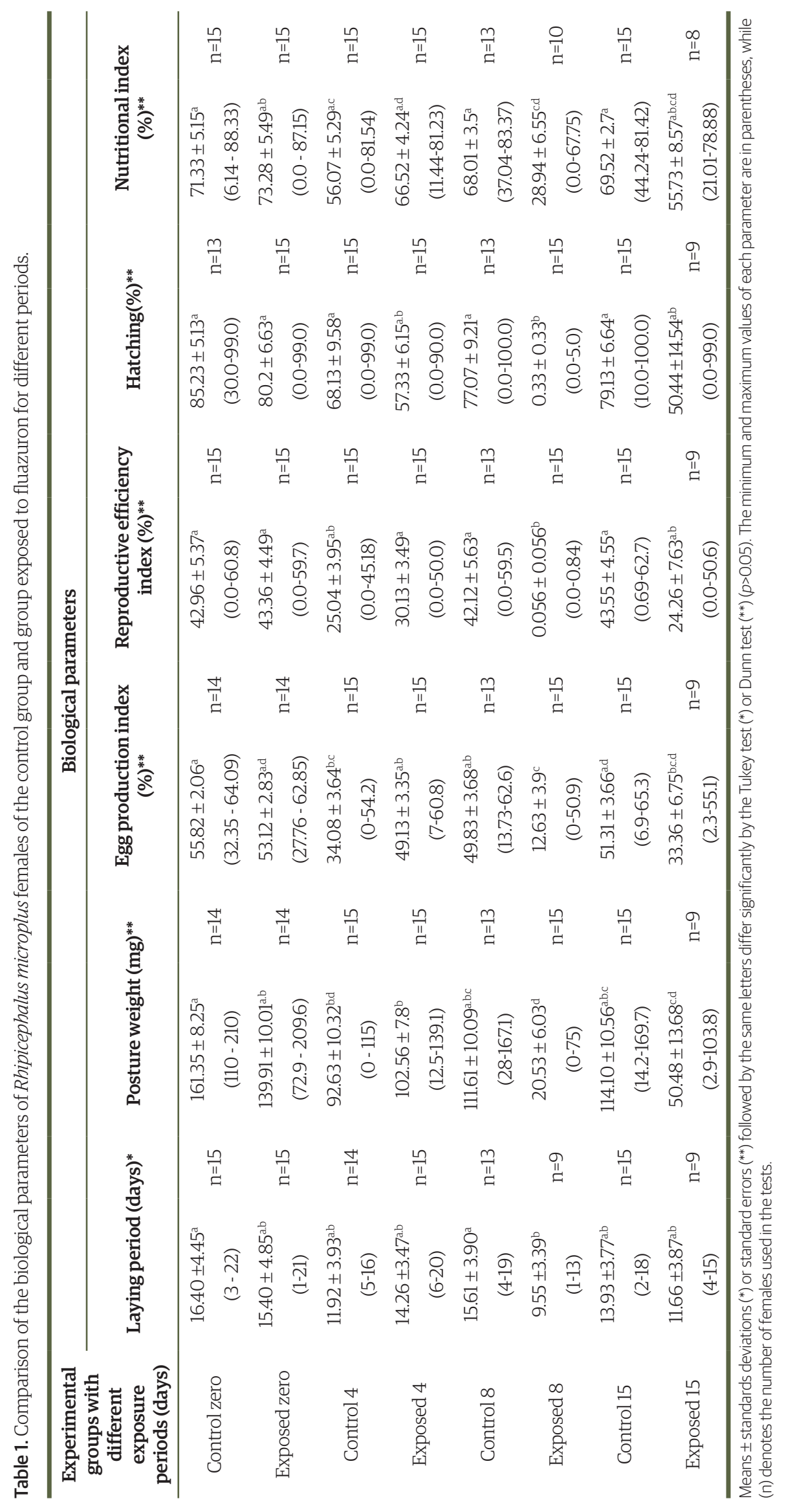


The nutritional index (NI) presented statistical differences $(p<0.05)$ between the exposed group on day $8(28.94 \pm 6.55 \%)$ and the control group on the same day $(68.01 \pm 3.5 \%)$, the control on day 0 (71.33 $\pm 5.15 \%)$, exposed on day $0(73.28 \pm 5.49 \%)$ and control on day $15(69.52 \pm 2.7 \%)$, demonstrating that the strongest effect of fluazuron on this parameter occurred 8 days after exposure to the product.

\section{Discussion}

The morphological alterations observed can be attributed to the inhibition of the synthesis of chitin in the female ticks, with consequent inefficient molting, resulting in body shape alterations. Previous articles have reported ultrastructural, cytological and histochemical alterations in Rhipicephalus sanguineus after ingesting blood containing the active principle fluazuron. Changes such as cuticle disorganization with absence of subdivisions, besides damages to cells of the tegument, epithelium and gut, have been attributed to problems in the absorption, digestion, distribution and synthesis of structural proteins, impairing ecdysis (Oliveira et al., 2012; Calligaris, et al., 2013; Oliveira et al., 2014).

On the 15th DAT, the average weight of the engorged females of the exposed group was the lowest among all the observation days, indicating an accumulative effect of exposure to fluazuron. These findings corroborate the effect of the product on this biological parameter since there was a significant difference between the control and exposed groups starting from the 4th DAT.

The expected average weight of a female at the end of the parasite phase was not attained by the females of the exposed group on any of the days after treatment. According to Oliveira et al. (2014), the damages caused to intestinal cells lead to inefficient absorption of nutrients. Oliveira et al. (2012) also reported effects of fluazuron on the formation of the chitinous structures responsible for tick feeding. The reduced size of the hypostome and chelicerae hampers ingestion of blood by the tick, leading to smaller weight gain.

Poorly developed chelicerae and hypostome hinder the tick in ingesting blood directly from the host's blood vessels, limiting its feeding only to the interstitial subcutaneous liquid, as observed in the feeding of ticks during younger stages (larva and nymph in initial feeding stage) (Tatchell \& Schuntner, 1972).

The weights of the engorged females and the spent females (after laying) are depicted in Figure 3. The other biological parameters are reported in Table 1.

Although the females started laying eggs with different average weights, they attained similar results at the end of the oviposition period, irrespective of their impaired nutritional status due to inefficient feeding. This suggests the possible existence of a metabolic regulatory mechanism that establishes a maximum limit for weight loss of females during posture. Based on this result, a set point might exist for regulation of body weight, inherent to the tick after laying, not according to the mass of eggs or nutritional demand of the progeny, so that the average final weight is virtually the same regardless of exposure to fluazuron.

The egg mass weight is directly related to the weight of the female at the end of a blood meal (Willadsen et al., 1984). Therefore, a feeding deficit due to the insufficient synthesis of chitin can lead to the lower weight of the engorged female, in turn causing a lower average weight of the eggs laid. This was mainly noted in the exposed group on day 8. In comparison to the average egg mass weight reported by Glória et al. (1993), of $155.3 \mathrm{mg}$, we observed much lower weights in the exposed group on days $8(20.53 \pm 6.03 \mathrm{mg})$ and $15(50.48 \pm 13.68 \mathrm{mg})$.

The great effect on the egg mass weight obtained on the 8th DAT affected the egg production index, as expected, which consequently showed the largest decline on that day. Like for the other parameters analyzed, the results obtained in this study for the control groups were very similar to those reported by other researchers, such as Glória et al. (1993), who observed mean IPI of 78.7\%.

The result of the reproduction efficiency index (REI) is due to the fact that the average body weight of the exposed group on day 8 was the lowest of all the observation days. This can be attributed to the greater effect of the product on this parameter after this interval. Borges et al. (2001) reported that the body weight of engorged females is directly related to the egg mass weight and that lighter females tend to show lower reproductive efficiency. Therefore, the lower REI observed in this study can be attributed to the lower mean weight of the exposed group in comparison with the control group, especially on the 8th DAT, in function of the treatment. 
The egg hatching percentage also declined due to the treatment. Many of the eggs laid by the ticks in the exposed group, particularly on the $8^{\text {th }}$ DAT, were "shriveled" (smaller size, with a dried and darkened aspect). Graf (1993) reported the ovicidal effects of benzoylphenyl ureas, attributing this to inhibition of the deposition of chitin by the developing larvae before hatching. Further according to him, since fluazuron impairs the tick's ingestion of blood from the host, the eggs produced have a lower hatching rate and the larvae that do hatch are less viable due to poor embryo development because of the trans-ovarian effect of the drug. Cruz et al. (2014) also observed a significant difference in the hatching percentage of $R$. microplus larvae when a pour-on formulation containing fluazuron was administered to cattle.

Because the nutritional index is calculated based on the egg mass weight, engorged female weight and spent female weight, that index clearly should reflect the changes in those three parameters. Therefore, the poor formation of the mouth apparatus mentioned previously, as reported by Oliveira et al. (2012), impaired the blood ingestion and reduced the mass of eggs produced, leading to a lower NI of the females, even though the average weight of the spent females was not affected by fluazuron.

Considering that the average life cycle of $R$. microplus is 18 to 22 days, measured from the larval stage on the host until the moment it stops feeding in the adult stage (Furlong \& Sales, 2007), the fact that the treatment with fluazuron had effects on the various development stages of the tick on the animal explains the heterogeneous results observed on the different evaluation days. In turn, this phenomenon can be explained by the fact that with only four days of exposure, the treatment effect is weaker due to the shorter time of ingestion of blood containing the active principal. According to Souza (2009), in a similar experiment with novaluron (an analog of fluazuron), also at a dose of $2.5 \mathrm{mg} / \mathrm{kg}$, the peak concentration (Cmax) of the drug in the host's bloodstream was $378 \mathrm{ng} / \mathrm{mL}$ for a maximum time (Tmax) of 4 days, and the area under the plasma concentration curve (AUC) was $>100$ ng for 28 days. Therefore, the ticks that fed up to the $4^{\text {th }}$ DAT and dropped off the host at the start of that day (6:30 A.M., when the ticks were collected in the stalls), probably did not absorb as much of the active principal as those that remained on the host after that day, ingesting blood containing a high fluazuron concentration. Although fluazuron can be detected in the plasma 16 hours after topical administration at a dose of $1.5 \mathrm{mg} / \mathrm{kg}$, the plasma concentrations appear to reach a high constant level only between 9 and 35 days after treatment (World Health Organization, 1997).

After eight days of feeding on the host, the ticks already ingested a considerable volume of blood containing the active principal. In this period, the females are passing from the larval to the nymph stage, a critical period for molting and feeding during which they are totally dependent on the synthesis of chitin and reformulation of the constantly expanding cuticle. Due to the critical nature of this period, it is logical to expect stronger effects of fluazuron after eight days than after four days. At the next moment of evaluation (15 days after treatment), the number of females recovered diminished considerably, indicating high mortality. However, the survival of some females, associated with attenuation of the effects on the biological parameters, leads us to believe in the possible development of resistance "strategies" by these females, allowing them to survive exposure to fluazuron from the larval to the adult stage.

In any event, after feeding for eight days, the survival of the engorged females, although still high, was accompanied by alterations of the biological parameters that will have long-term effects on the tick population.

\section{References}

Benetti, G.F. (1974). Oviposition of Boophilus microplus (Canestrini, 1987) (Acarina: Ixodidae). I. Influence of tick size on egg production. Acarologia, 16(1), 52-61. PMID: 4463680.

Borges, L. M. F., Carneiro, J. R. C., Gomes, A. G., \& Moreira, P. C. (2001). Influência do peso inicial e da estação do ano na conversão em ovos de fêmeas de Boophilus microplus (Acari: Ixoxidae). Ciência Animal Brasileira, 2(2), 127-131.

Calligaris, I. B., Oliveira, P. R., Roma, G. C., Bechara, G. H., \& Camargo-Mathias, M. I. (2013). Action of the Insect Growth Regulator Fluazuron, The Active Ingredient of the Acaricide Acatak VR, in Rhipicephalus sanguineus nymphs (Latreille, 1806) (Acari: Ixodidae). Microscopy Research and Technique, 76(11), 1177-1185. http://dx.doi. org/10.1002/jemt.22282. PMid:24000046. 
Cohen, E. (1987). Chitin biochemistry: synthesis and inhibition. Annual Review of Entomology, 32(1), 71-93. http:// dx.doi.org/10.1146/annurev.en.32.010187.000443.

Cordovés, C. O. (1997). Carrapato: control ou erradicação (1st ed., 176 p.). Guaíba: Agropecuária.

Cruz, B. C., Teixeira, W. F. P., Maciel, W. G., Felippelli, G., Fávero, F. C., Cruz, A. C., Buzzulini, C., Soares, V. E., Gomes, L. V. C., Lopes, W. D. Z., Oliveira, G. P., \& da Costa, A. J. (2014). Effects of fluazuron (2.5mg/kg) and a combination of fluazuron $(3.0 \mathrm{mg} / \mathrm{kg})+$ abamectin $(0.5 \mathrm{mg} / \mathrm{kg})$ on the reproductive parameters of a field population of Rhipicephalus (Boophilus) microplus on experimentally infested cattle. Research in Veterinary Science, 97(1), 80-84. http://dx.doi.org/10.1016/j.rvsc.2014.04.012. PMid:24837997.

Furlong, J., \& Sales, R. O. (2007). Control estratégico de carrapatos no bovino de leite: uma revisão. Revista Brasileira de Higiene e Sanidade Animal, 1(2), 44-72. http://dx.doi.org/10.5935/1981-2965.20070009.

Glória, M. A., Faccini, J. L. H., Daemon, E., \& Grisi, L. (1993). Biologia comparativa da fase não parasitária de estirpes de $B$. microplus (Can., 1887) resistente e sensível a carrapaticida em condições de laboratório. Revista Brasileira de Parasitologia Veterinária, 2, 79-84.

Graf, J.-F. (1993). The role of insect growth regulators in arthropod control. Parasitology Today, 9(12), 471-474. http://dx.doi.org/10.1016/0169-4758(93)90106-P. PMid:15463697.

Grisi, L., Leite, R. C., Martins, J. R. S., Barros, A. T. M., Andreotti, R., Cançado, P. H. D., Léon, A. A. P., Pereira, J. B., \& Villela, H. S. (2014). Reassessment of the potential economic impact of cattle parasites in Brazil. Revista Brasileira de Parasitologia Veterinária, 23(2), 150-156. http://dx.doi.org/10.1590/S1984-29612014042. PMid:25054492.

Klowden, M. J. (2007). Integumentary systems. In M. J. Klowden. Physiological systems in insects (Chapter 2, 2nd ed., pp. 75-135). London: Academic Press.

Meléndez, R. D., Coronado, A., Mujica, F., Cerutti, F., \& Mosquera, O. (1998). Levels of natural resistance two Boophilus microplus (Acari: Ixodidae) in Corora breed bulls. Revista de Biología Tropical, 46(3), 691-696. PMid:10347818.

Oliveira, P. R., Calligaris, I. B., Nunes, P. H., Bechara, G. H., \& Camargo-Mathias, M. I. (2014). Fluazuron-induced morphological changes in Rhipicephalus sanguineus Latreille, 1806 (Acari: Ixodidae) nymphs: An ultrastructural evaluation of the cuticle formationand digestive processes. Acta Tropica, 133, 45-55. http://dx.doi. org/10.1016/j.actatropica.2014.01.008. PMid:24508101.

Oliveira, P. R., Calligaris, I. B., Roma, G. C., Bechara, G. H., Pizano, M. A., \& Mathias, M. I. C. (2012). Potential of the insect growth regulator, fluazuron, in the control of Rhipicephalus sanguineus nymphs (Latreille, 1806) (Acari: Ixodidae): Determination of the LD95 and LD50. Experimental Parasitology, 131(1), 35-39. http://dx.doi. org/10.1016/j.exppara.2012.02.023. PMid:22465612.

Palli, S. R., \& Retnakaran, A. 1999. Molecular and biochemical aspects of chitin synthesis inhibition (pp. 85-98). In P. Jolles, R. A. A. Muzzarelli (Eds.), Chitin and Chitinases. Basel: Birka user Verlag. http://dx.doi. org/10.1007/978-3-0348-8757-1_6.

Pereira, M. C., Labruna, M. B., Szabó, M. P. J., \& Klafke, G. M. (2008). Rhipicephalus (Boophilus) microplus. Biologia, control e resistência (1a ed., 169 p.). São Paulo: Med Vet.

Sonenshine, D. E. (1991). The biology of ticks. New York: Oxford University Press.

Souza, G. S. (2009). Avaliação da atividade do novaluron, sobre Boophilus microplus (Canestrini) em bovinos de corte naturalmente infestados (Dissertação de mestrado). Universidade Católica de Goiás, Goiânia.

Tatchell, R. J., \& Schuntner, C. A. (1972). Glucose metabolism in the cattle tick Boophilus microplus. Journal of Insect Physiology, 18(2), 283-288. http://dx.doi.org/10.1016/0022-1910(72)90128-X.

Vasuki, V.; Rajavel, A. R. (1992). Influence of short time exposure to an insect growth regulator, Hexaflumuron, on mortality and adult emergence of vector mosquitoes. Memórias do Instituto Oswaldo Cruz, 87(2), 275-283.

Willadsen, P., Kemp, D. H., \& Mckenna, R. V. (1984). Bloodmeal ingestion, and utilization as a component of host specificity in the tick, Boophilus microplus. Zeitschrift for Parasitenkunde, 70(3), 415-420. http://dx.doi, org/10.1007/BF00927829.

World Health Organization - WHO. (1997). Toxicological evaluation of certain veterinary drug residues in food. Geneva: International Programme on Chemical Safety.

World Health Organization - WHO. (1998). Residues of some veterinary drugs in animals and foods (48-55). Rome. 